\title{
THE IMPLEMENTATION OF DRINKING WATER SUPPLY SYSTEM IN DECENTRALIZATION ERA
}

\author{
Wasifah Hanim \\ wasifah.hanim@widyatama.ac.id \\ Pascasarjana Department Widyatama University Bandung Indonesia \\ Jl. PHH Mustafa No. 59 Bandung \\ Jawa Barat, Indonesia 40124
}

received: 5/9/18; revised: 18/9/18; published: 31/12/18

\begin{abstract}
This study aims to analyze the system of drinking water management in the decentralization era and to to analyze of the difference of community accessibility to drinking water between before and after the era of decentralization. The analytical method used is descriptive method, which is analyzing the implementation of drinking water supply systems (DWSS) in the decentralization era and average difference test to determine the development of community accessibility to drinking water before and after decentralization era. The result shows that decentralization provides a positive development towards the implementation of the drinking water supply system, namely by increasing the number of districts/cities that have DWSS planning documents but statistically the decentralization era did not increase the growth of drinking water coverage.
\end{abstract}

Keywords: supply; system; drinking water; implementation; decentralization

\section{INTRODUCTION}

Drinking water is one of human basic needs which is necessary to improve the quality of human life a region. The availability of clean water or drinking water is closely related to the level of welfare of people in a region or country. Along with increasing the population growth, it increases the need for clean water. There is a tendency for countries with higher income levels to tend to have higher levels of water use. Meanwhile, the availability of water resources may be limited (Sullivan, 2002).

Drinking water in the economic context has an important role, namely as an indicator of poverty. The decline in poverty and inequality remains an important policy goal in most countries, especially in developing countries. (Sepulveda \& Martinez-Vazquez, 2011) Poverty is defined from a variety of dimensions, the population is said to be poor not only as a result of shortcomings in meeting their minimum physical needs, but also because of low accessibility to the provision of infrastructure, including clean water or drinking water.

Based on the World Bank in study in Honduras (2011) showing that increased access to clean water through a water pipeline program increased the average income of households with access to clean water by 7.32 percent. While the Sri Lanka (1998) study found that the economic benefit of providing access to clean water is the time substitution of housewives to the labor market. Prior to the clean water project, most housewives spent time to lift water from a spring or river. After water access has been channeled to the villages, there has been an increase in the participation of female labor force, especially housewives to formal and informal employment markets. This increase in female labor participation is predicted to increase household income by almost $20 \%$ per month (Sukartini \& Saleh, 2011).

There are several mechanisms for the transmission of water access points on economic aspects such as: 1. Productivity and income lines, 2. sanitation and health lines, 3 education channels. In the transmission of productivity and earnings increases, the linkage of access to clean water with increased productivity and income opportunities, obtained from participating reporting that increased access to clean water in urban and rural areas, especially among the poorest (Sukartini \& Saleh, 2011).

Therefore, increasing availability of clean water or drinking water is closely related to poverty alleviation. One of the national development priorities is to reduce poverty, increasing the availability of drinking or clean water will reduce poverty. How important poverty alleviation is, Indonesia together with 190 other countries have agreed on 17 sustainable development agendas set out in the Sustainable Development Goals (SDGs). The first agenda is to end poverty in all its 
forms everywhere, related to and the sixth agenda is to ensure the availability and management of sustainable water and sanitation for everyone (GTLRG, 2016).

With the implementation of autonomy, districts and cities has the authority to formulate policies and programs development in accordance with regional aspirations and needs. District and city governments are expected to become more responsive in responding to various problems that develop in the area so that development programs are implemented according to the needs and problems in the region. Regions also have the authority to allocate budgets according to priorities and regional needs. With conditions like this, the program and district and city government policies will be better able answer community needs (Hamid, 2014).

Along with SDGs targets, Indonesia has a policy to achieve $100 \%$ access to safe drinking water by 2025 . Existing conditions indicate that in 2013 the coverage of drinking water services in Indonesia was $67.73 \%$ in 2017 to $72.04 \%$ so within 4 year increased by $4.31 \%$ (BPS, 2018). Therefore, it requires the acceleration of the Development of Drinking Water Supply Systems (DWSS) to achieve targets in accordance with the Government's targets and SDGs.

In accordance with the spirit of regional autonomy as stated in the Law of the Republic of Indonesia Number 23/2014 concerning Regional Government, which was then followed up with Government Regulation No. 16/2005 concerning Development of Drinking Water Supply Systems (DWSS) which confirms that the implementation of drinking water services is the duty and responsibility of the Central Government and Regional Governments. This paper tries to explain how the authority of the central and regional governments in the provision of drinking water and whether there are significant differences in the acceleration of the coverage of drinking water services in the era of decentralization.

The starting point of the thought of regional autonomy is as an effort to create a maximum public service system (Kabir, 2016). Indonesia as a country with thousands of islands has different characteristics in each region. These differences encourage differences in community needs, differences in development in each region (Sianturi, 2011). The existence of differences in public service preferences in each region, the standard services provided by the central government are considered less efficient. Therefore, local governments are more suitable to provide services because local governments are assumed to understand the unique preferences of each region (Zakaria, 2013). Therefore the implementation of regional autonomy which has been immediated since 1999 as fulfillment of the indonesian people's demands in the framework of accommodating the variety of indonesian community needs.
Decentralization is the submission of Government Affairs by the Central Government to autonomous regions based on the Autonomous Principle (UU Otonomi Daerah nomer 23 tahun 2014). Thus the implementation of government based on decentralization can also be seen as a reduction in the dominance of the central government and giving up some authority to the regional government (Martinez-Vazquez \& McNab, 2003). The devolution of authority is accompanied by financial transfer, both revenues and expenditures which are called fiscal decentralization.

Decentralization will affect the implementation of the public sector, both quantity and quality. Fiscal decentralization will encourage the allocation of public sector resources more efficiently. Differences in preferences and community needs for public services in each region will be more appropriate if provided by the local government. Tiebout (1956) states that not all public service provision must be provided by the central government, some public services are more appropriate if provided by local governments such as education, hospitals, etc. As well as Oates (1993) The basic concept of fiscal decentralization is the improvement of economic efficiency in the provision of public goods in accordance with the tastes and circumstances of the region, this will result in higher levels of community welfare (Hanim, 2018).

The development of Drinking Water Supply System (DWSS) is an activity that aims to build, expand and/ or improve the physical (technical) and non-physical (institutional, management, financial, community and law) systems in a unified whole to implement drinking water supply to the society towards better condition. In relation to the provision of drinking water, the law mandates that DWSS development is the task of government, both central and regional governments. Given the critical importance of drinking water supply to the entire community, various laws and regulations are issued for the implementation of DWSS development.

Authority and responsibility of DWSS Development is the responsibility of the the central and regional government to ensure the right of every person in getting drinking water for basic daily needs to meet a healthy, clean, and productive life. The authority and responsibility of the government in the development of DWSS is set forth in the Government Regulation of the Republic of Indonesia No. 16/2005 on Development of Drinking Water Supply System article 38,39 and article 40 as shown in Table 1.

The implementation of DWSS development in the decentralization era regulated in Government Regulation No. 16/2005 and No. 38/2007, which contain the authorities and responsibilities of local governments in the development of DWSS, namely: (1) Arranging Regional Strategic Policy of DWSS development; (2) Arranging Regional Regulation about the Formation of Regional State Owned Enterprises; (3) 
Arranging Guidelines for the development of DWSS Master Plan; (4) Preparing Feasibility Study of DWSS Development; (5) Establishing Technical Planning of DWSS Development; (6) Arranging regulations/ legal products related to the action plan of application acceleration of Minimum Service Standards (MSS).

\section{METHOD}

In this study, the author used secondary data, data requirements are obtained from Basic Health Research Book of 2013 published by Ministry of Health, Performance Book of Drinking Water Supply Institution Region I - IV issued by Ministry of Public Works Supporting Agency for Development of DWSS and Result of National Recap of June 13, 2014, from Directorate of Improving Dringking Water of Public Works year 2014 and drinking water coverage data in districts in Indonesia before the decentralization era (1993-1999) and after the decentralization era (20002010). basic consideration for determining the 20002010 period, because in 2011 until now the calculation of drinking water coverage is worth using a new method.

This research is a descriptive study which aims to analyze the implementation of the drinking water system in Indonesia in the era of decentralization. the method carried out is by analyzing the authority of the central and regional governments in the implementation of the development of drinking water supply system based (DWSS) on the laws and regulations. Analysis of the development of drinking water service coverage before and after the decentralization era, was carried out by examining the differences in the average growth of decent drinking water coverage between before and after the decentralization era, namely using the average difference test.

Indicators used in PDAM performance evaluation are the result of perfection in 2010 which was done by using Balance Score Card approach by measuring the health level of PDAM. Some indicators used to measure PDAM performance are financial, service, operational and human resources aspects of PDAM. Each aspect is broken down into several service indicators for the development of drinking water supply systems, and the results of the assessment are categorized into 3 (three) criteria, ie healthy PDAMs, less healthy PDAMs , and not healthy PDAMs.

\section{RESULTS AND DISCUSSION}

In 2012, performance evaluation was conducted on 328 PDAMs throughout Indonesia, the results showed that the number of healthy PDAMs was $52.13 \%$ out of 328 PDAMs, while the percentage of PDAMs with less healthy performance was $30.79 \%$ and the PDAM with not healthy performance was $17,07 \%$. In its development, the number of PDAM conducted by performance evaluation by Supporting Agency for DWSS for three years has decreased. As the number of PDAMs evaluated decreases, it will cause changes in the number and percentage of each criterion.

Within 3 (three) years, the number of healthy PDAMs showed a positive trend. Based on existing data, the number of healthy PDAMs in 2010 as many as 142 PDAMs, in 2011 increased to 144 PDAMs and in 2012 increased significantly by 171 PDAMs. In other words, in 2011 the percentage of healthy PDAM increased by $1.41 \%$ and in 2012 increased by $18.75 \%$. In line with the increasing number of healthy PDAMs, it is expected that there will be an increase in the quality and quantity of PDAM services to the community. The improvement of PDAM performance evaluation results for 2010, 2011 and 2012 can be seen in the Table 2 .

Table 2.The Improvement of PDAM Performance in Indonesia Period 2010-2012

\begin{tabular}{lccccc}
\hline Performance & 2010 & Growth & 2011 & Growth & 2012 \\
\hline Healthy & 142 & 1,41 & 144 & 18,75 & 171 \\
Less Healthy & 129 & $(18,60)$ & 105 & 5,71 & 111 \\
Not Healthy & 70 & 22,86 & 86 & $(34,88)$ & 56 \\
\hline Jumlah & 341 & \multicolumn{5}{c}{335} & 328 \\
\hline Source: & Book of PDAM Performance Year 2012, Supporting \\
\multicolumn{7}{c}{ Agency of DWSS }
\end{tabular}

Clean water service is a very important component in public services. Water is a basic need that can not be separated from human life. The provision of clean water to the special attention of every country in the world is no exception in Indonesia. Population growth, development growth, and rising standards of living cause the increasing need for clean water. This makes the quality of service providers and managers of clean water is needed by the community.

In the era of regional autonomy, decentralized water resources management aims to bring the service closer together, strengthen control and participation of communities on the use of water and springs (sources), water pollution and environmental degradation. The decentralization of local government that occurs in clean water is left entirely to PDAMs that have the authority to manage and distribute water to the people of Indonesia. To meet the water needs of the community, PDAM uses water from water sources or water management (Pranata, Soeaidy, \& Hanafi, 2015).

Drinking Water Supply Institution (PDAM) shall carry out the main duty to manage and give service of clean water to improve the welfare of the community in accordance with the Law no. 23/2014, on Regional Government. As one of the regional-owned enterprises, they should strive to be able supporting the realization of the mission and functions. Therefore, the management of drinking water system should be done properly and correctly and should meet technical and economic norms 
in accordance with predefined criteria standards. Based on average coverage of PDAM services in Indonesia in 2014, none reached 50\%. Even the highest coverage of drinking water services by PDAM is $45.28 \%$ in Central Java Province, followed by PDAM Riau Islands Province of $40.88 \%$ while the lowest coverage of drinking water services by PDAM is Lampung Province which is only $3.44 \%$ (Table 3 ).

In accordance with the mandate of Government Regulation No. 16/2005 regarding the obligations of district/city governments in DWSS development, among others stated that the hours of drinking water services to the community reach 24 hours a day. Based on the data of drinking water services obtained from the Directorate of Drinking Water of Cipta Karya the Ministry of Public Works, shows that the average hours of drinking water services by PDAM are less than 24 hours a day. Only the PDAM of DKI Jakarta Province provides 24 hours daily service. The province with the fewest hour of PDAM service is Riau Province with service only 9 hours per day.

Clean Water Supply has an important role in regional development, chapin in 1995 revealed that there are three city infrastructure that is very influential for the development of the city of transportation, clean water and sewage. These three types of infrastructure should be available for the construction of a city to proceed as planned. Thus the provision of clean water is one of the most important things since clean water is a basic necessity that is always consumed by the community (Susanti, 2010).

The availability of clean water will encourage the availability of appropriate drinking water for the community. the availability of drinking water is closely linked to poverty, therefore the target of all communities in Indonesia can access safe and proper drinking water to be one of Indonesia's agenda in Sustainable Development Goals (SDGs).

Achieving the target of $100 \%$ safe drinking water by 2019 , this region needs careful planning as a reference in the implementation of drinking water supply. Decentralization has a positive impact on the development of the water sector, in the planning aspect, decentralization has encouraged regions to develop the DWSS master plan. Regions must prepare planning documents within the DWSS development framework for the 20-year planning period, namely RISPAM. Most districts/cities in Indonesia are in the process of drafting the DWSS Master Plan. in 2014 there were 106 districts/cities that had compiled the DWSS Master Plan (Ditpam,2014). In 2017 there was a large increase, from 508 districts/cities, only 32 districts/cities that had not completed the DWSS Master Plan document (RISPAM) (Ciptakarya,2017).

Whereas the outcome aspect can be seen based on the growth of decent drinking water coverage by households. Comparing the average growth of adequate drinking water coverage between the period before and after decentralization shows that decentralization has no difference in the growth of household drinking water coverage. Statistically obtained t statistic values of -0.05 and $p$ value of 0.478 .

The statistically insignificant value shows that decentralization has no effect on public services, this is in line with the research conducted by Sulistyarini (2004). His research on the impact of decentralization on the quality of public services in the case of the health sector in the City of Yogjakarta. important conclusions include the health sector is only still a source of regional retribution and the Yogyakarta City Government does not have a comprehensive and operational health development management in the long term and relevant to the needs of the community. Likewise research conducted by Huda \& Sana (2013) on the effect of fiscal decentralization on school participation rates, the resulting effect was found to be insignificant.

Thus the local government is also required to fix its infrastructure with regard to technical implementation, procedures, systems and working mechanisms between all stake holders in the implementation of drinking water supply. The spirit of reform and regional autonomy that spreads across all segments of society today, would be the right momentum to implement the ideas of development and improve the quality of public services, especially related to the drinking water sector (Hamid, 2014).

\section{CONCLUSION}

The authority and responsibility in DWSS development becomes the authority of Central Government when the location of activities, users, benefits are cross-provincial, when the use of resources shall be more efficient if carried out by the central government; and/or when it is strategic role for the national interest. The authority and responsibility in DWSS development becomes the authority of the Provincial Government when the location of activities, users, benefits are cross-district and when the use of resources is more efficient if carried out by the provincial government. The authority and responsibility in DWSS development becomes the authority of the District/ City Government when the location of activities, users, benefits are cross-district and then the use of resources is more efficient if carried out by the district/ city government.

Actually the implementation of regional authority in the provision of clean water in planning aspects has been implemented. Most districts/cities have compiled a master plan for the development of drinking water. However, if it is chosen from the development of growth in the coverage of drinking water services, it indicates that decentralization has not been able to accelerate the growth of drinking water coverage. for this reason, 
cooperation between the central and provincial and district/city governments is needed to find solutions to improve the coverage of decent drinking water. One of main of problem occurred in district/city related to DWSS Development is raw water because the tendency is cross district/city. Therefore, facilitation from the Central Government and Provincial Government is needed to accelerate the settlement of inter-regional conflict related to raw water.

\section{REFERENCES}

Direktorat Pengembangan Air Minum Kementerian Pekerjaan Umum (Ditpam). 2014. Hasil Rekap Nasional Per 13 Juni 2014.

Government Regulation No. 16/2005 on Development of Drinking Water Supply System.

Government Regulation No. 38/2007 on the Division of Government Affairs. GTLRG, 2016. For Localizing The SDGs : 44.

Kementerian Kesehatan. 2013. Riset Kesehatan Dasar.

Kementerian Pekerjaan Umum BPSPAM. 2013. Kinerja PDAM wilayah I- IV.

Law No. 23/2014 on Regional Governance

Hamid, A.A., 2014. Otonomi Daerah dan Kualitas Pelayanan Publik. Academica 3, 535-546.

Hanim, W., 2018. The Implementation of Special Allocation Fund Policy For Rural Transportation Sector 2, 37-50.

Huda, N. A. and Sasana, H. 2013. Analisis Dampak Desentralisasi Fiskal Terhadap Outcomes Pelayanan Publik Bidang Pendidikan (Studi Kasus: Provinsi DKI Jakarta). Diponegoro Journal of Economics, 2, pp. 1-13.

Kabir. 2016. Pelayanan Publik Dalam Kerangka Otonomi Daerah 709-716.

Martinez-Vazquez, J., McNab, R.M. 2003. Fiscal decentralization and economic growth. World Dev. 31, 1597-1616.

Martinez-vazquez, J. and Rider, M. 2006. Fiscal
Decentralization and Economic Growth : a Comparative Study of China and India. Indian Journal Of Economics And Business, (Special Issue China and India), pp. 1-18. doi: 10.2139/ ssrn. 259281.

Pemoderasi, S. V. et al. 2015. Media Ekonomi dan Manajemen Vol. 30 No. 1 Januari 2015. Untag Semarang, 30(1), pp. 85-100.Pendidikan, P. B. (no date) 'No Title', pp. 81-96.

Pranata, A., Soeaidy, M.S., Hanafi, I. 2015. Kerja Sama Antar Pemerintah Daerah Dalam Pengelolaan Sumber Daya Air (Studi Pada Kerja Sama Kota Malang dengan Kota Batu dan Kota Malang dengan Kabupaten Malang Dalam Pengelolaan Sumber Daya Air). J. Adm. Publik 3, (1787-1791).

Sacchi, A. and Salotti, S. 2011. Income inequality, regional disparities, and fiscal decentralization in industrialized countries. Workshop on Regional and Urban Economics: Inequality and Regional Growth and Cohesion, (November), pp. 14-15.

Sepulveda, C.F., Martinez-Vazquez, J. 2011. The consequences of fiscal decentralization on poverty and income equality. Environ. Plan. C Gov. Policy 29, 321-343.

Sianturi, Y.S. 2011. Dampak Desentralisasi Fiskal Terhadap Ketimpangan Pendapatan Antar Wilayah (Studi Kasus Kabupaten/Kota Propinsi Sumatera Utara).

Sukartini, N.M., Saleh, S. 2011. Akses Air Bersih di Indonesia Access to Clean Water in Indonesia. J. Ekon. Kuantitatif Terap. 9, 89-98.

Sullivan, C. 2002. Calculating a Water Poverty Index. World Dev. 30, 1195-1210.

Susanti, R. 2010. Pemetaan Persoalan Sistem Penyediaan Air Bersih Untuk Meningkatkan Kualitas Sistem Penyediaan Air. J. Wil. dan Perenc. Kota 21, 111-128.

Zakaria, S. 2013. The Impact of Fiscal Decentralization toward Regional Inequalities in Eastern Region of Indonesia. J. Econ. Sustain. Dev. 4, 74-85. 
Table 1. Authority and Responsibility of Government in DWSS Development According to Government Regulation No. 16/2005

Central Governmen Province Government District/City Government

(Article 38)

(Article 39)

(Article 40)

a. Establishing national a. Arranging policies and a. Arranging policies and strategies in their regions based on policies and strategies; development strategies in its

b. Establishing norms, territories based on national national policies and strategies and provincial policies and strategies; standards, guidelines and manuals; policies and strategies;

c. Establishing SOEs operating DWSS; facilitating resolution of problems among provinces, which are specific, strategic, both national and international;

b. Facilitating DWSS

b. Can form a Regional-Owned Enterprises to provide DWSS development;

development across districts/ c cities;

c. Establishing a provincial Regional Owned Enterprises as a provider of DWSS;

d. Solving problems between districts/cities;

e. Conduct monitoring and evaluation of the districts/ cities;

assistance and conduct controls, as well as supervision of the organization;

e. Granting inter provincial licenses;

f. Determining raw water allocation for DWSS development needs in accordance with defined water use rights; and

g. Facilitating the fulfillment of raw water requirements for DWSS development needs in accordance with their respective authorities. f. Submitting reports on results of monitoring and evaluation of the implementation to the Government and Supporting Agency for DWSS Development;

g. Giving permission for crossdistrict/city administration;

h. Facilitating the fulfillment of $j$. raw water requirements for DWSS development needs in accordance with their respective authorities. c. Fulfilling the drinking water needs of the community in its territory in accordance with specified minimum service standards;

d. Fulfilling the needs of sanitation services to improve the health of the community in its territory in accordance with established minimum service standards;

e. Ensure the continuity of DWSS development in its territory;

f. Carrying out the procurement of construction services and / or the establishment of DWSS development in areas not yet reached by Regional-Owned Enterprises services;

g. Providing technical assistance to the subdistrict, village government, and community groups in the region regarding to the implementation of DWSS development;

h. Conduct monitoring and evaluation of the implementation of DWSS development in its territory;

i. Submitting reports on results of monitoring and evaluation of the implementation to the provincial government, central government and Supporting Agency of DWSS Development; Supervising the implementation of DWSS development in its territory;

k. Provide permission to implement DWSS development in its territory; and

1. Facilitating the fulfillment of raw water requirements for DWSS development needs in accordance with their respective authorities.

Table 3. Service Hours of PDAM in Indonesia based on Province in 2014

\begin{tabular}{cccl}
\hline No & $\begin{array}{c}\text { Service hours } \\
\text { of PDAM }\end{array}$ & $\begin{array}{c}\text { Number of } \\
\text { Province }\end{array}$ & Province \\
\hline 1 & 9 & 1 & Riau \\
2 & 10 & 2 & Sumatera Selatan, Papua Barat \\
3 & 11 & 3 & Jambi, Lampung, Bangka Belitung \\
4 & 13 & 1 & Kalimantan Tengah \\
5 & 15 & 4 & Aceh, NTT, Kalimantan Timur Dan Sulawesi Tenggara \\
6 & 17 & 6 & Sumatera Utara, Kalbar, Kalsel, Gorontalo, Sulbar dan Sumbar \\
7 & 18 & 2 & Sulawesi Utara dan Papua \\
8 & 19 & 3 & Kepulauan Riau, DIY dan Sulawesi Selatan \\
9 & 20 & 4 & Sumatera Barat, Banten, Bengkulu dan NTB \\
10 & 21 & 2 & Jawa Tengah dan Maluku Utara \\
11 & 22 & 2 & Jawa Barat dan Sulawesi Tengah \\
12 & 23 & 1 & Bali \\
13 & 24 & 1 & DKI Jakarta \\
\hline
\end{tabular}

Source: Ditpam, 24 ${ }^{\text {th }}$ Februari 2014, processed 